\title{
Municipal gardens as the synergic element of the structure of selected towns of Lublin region
}

\author{
Kamila Lucyna Boguszewska \\ Independent Architectural Design Studio, Lublin University of Technology, \\ k.boguszewska@pollub.pl,ORCID: 0000-0002-1513-2490
}

\begin{abstract}
Planning of municipal gardens as the integral part of urban landscape in the Lublin region was typified by the activity of the outstanding garden planners: engineer Feliks Bieczyński and Walerian Kronenberg. This movement to create public, municipal green areas commenced in $19^{\text {th }}$ century and continued with success during the inter-war period. This process took place in the big cities of Lublin, Zamość or Lubartów. Newly established public gardens were usually located on the outskirts of the city as for example, Park Saski (1837), Ogród Bronowicki (the Bronowicki Garden) - formerly called the Foksal Park in Lublin, or Park Miejski im. Jana Kanclerza Zamoyskiego (the Zamoyski Municipal Park - 1926) located in the former fortification area in Zamość. The situation in smaller cities such as Lubartów, Radzyń Podlaski (1755, planner: Jakub Fontana) and Kock (planner: Szymon Bogumił Zug) was slightly different. The former garden complex adjacent to the magnate residence served a key role in the urban structure of the settlement (thus, determining its development) was later adapted to the function of a municipal park.

The article describes three selected garden complexes. The spatial relations of the parks in the context of their urban structure are analysed. The article takes into account their contemporary use and the state of preservation of their historic elements as presented in the original composition as presented in historic images and maps.
\end{abstract}

Keywords: municipal park, garden architecture, the $19^{\text {th }} / 20^{\text {th }}$ century, the Lublin region

\section{Introduction}

The development of municipal parks in Poland started in the $19^{\text {th }}$ century due in an effort to organize and regulate the cities. Public greenery gained then an autonomous function, becoming an important element for spatial and urban planning of the developing cities of Lublin region [1]. Some of the new garden complexes were located on the city outskirts, often near tollbooths or entry gates, often in demanding and difficult areas due to the terrain, remnants of ancient fortifications, or problematic infrastructure issues in and arounds areas designated for the public parks.

Municipal parks were considered to be the opportunity for improving the sanitary and hygienic conditions of the city and for increasing aesthetics qualities, for the developing parts of the city. Creating city parks from existing older gardens of palaces, manors, and monasteries had its own challenges. These parks are most often located near the market squares located in the very centre of the towns. By making them public, they became an important green area for the entire urban layout and determined the street layout [2]. 


\section{The state of research}

The subject of municipal parks in Lublin Voivodship have not been fully investigated. The principles of the design of calligraphy parks, the work of Walerian Kronenberg were described by V. Kulus [3]. The monograph devoted to the planner presented the main doctrines of his workshop in creating urban parks. P. Baster (2011) analysed the garden complexes of Kronenberg with particular emphasis on the manored and palace parks [4]. The history the municipal park in Zamość was described by B. Sawa [5]. The analysis of dendroflora and state of preservation of the park in Czesławice by Walerian Kronenberg was carried out by K. Pudelska and K. Rojek [6].

The establishment of the palace park complex in Lubartów and its transformations was the subject of the articles by M. Kseniak [7] and E. Przesmycka [8]. The architecture of the greenhouse/hothouse in this complex was described by, among the others, Grytczuk, Kuźmicz [9] and K. Boguszewska [10], [11]. The municipal park in Lublin called the Ogród Saski was the subject of research and articles of J. Niedźwiedź [12] and N. Przesmycka [13].

\section{The purpose and scope of work}

The article shall present three municipal parks of the Lublin region, specifically the parks of Lublin, Lubartów and Zamość. The common denominator of these public spaces is the function they fulfil today. The article analyses the changes in the form and function of the historic structure of three parks, approaches to their restoration and the nature of their complementary infrastructure, including hothouse and greenhouse as the nodal architectural elements.

\section{History of establishing of municipal gardens}

The first public gardens were mostly complexes accompanying palaces and monasteries. Examples of this include the gardens of Warsaw: Ogród Saski (palace park) 1727, Ogród Krasińskich (palace park) - 1768, Ogród ks. Podkomorzego - 1780 (manor garden), and Łazienki Królewskie (palace park). In the 19-th century these were opened for the residents of Warsaw.

The first municipal parks in the Congress Poland were established in Kalisz (converted former Jesuit garden) and Łęczyca at the end of the $18^{\text {th }}$ century. Later, parks were created in: Kielce in 1815 (former bishop's garden), Sieradz in 1825, Konin in 1825, Częstochowa in 1826, Janów Lubelski in 1830, Radom in 1834, Suwałki in 1832, Płock, Sandomierz in 1859 and Lublin in 1837 [14].

In 1892, Edmund Jankowski described the state of public gardens in the Congress Poland. In his article "On public gardens in provincial cities" (original title: „O Ogrodach publicznych $w$ miastach prowincjonalnych") he stated: "In truth, a few larger cities like Lublin, Kielce, Sandomierz or Ptock finally have good public gardens, but these complexes are also flawed when viewed by an expert. Lack of views, roads led without a reasonable need, common planting material, and above all, not watered, hence poor lawns. This is all too noticeable. You clearly see the lack of a good plan of the complexes, inappropriate management at the execution, and in many cases, inability to maintain gardens, and, without doubt, everywhere, the meagreness of funds to maintain gardens designated for municipalities" [15]. This brief description presents the problems that the institutions responsible for establishing and maintaining public gardens at the turn of the $20^{\text {th }}$ century were facing. E. Jankowski in his paper encourages "provincial cities" to take care of the 
greenery in the centre and to plant trees along the streets; he emphasizes the advantages and benefits of an extensive greenery system in the urban structure from "hygienic benefits" to "social life nodes".

Particular emphasis was placed on the method of financing of the so-called "Plantations". E. Jankowski argued that the basis is a good "plan (...), which then has to be performed in stages, even for a dozen or so years, but it needs to be done to the letter, with iron perseverance". He also notices that after having analysed the plans of public parks of cities and towns, it can be seen that "almost none of them had an original plan, made by competent, well-educated and experienced gardeners - artists" [15].

At the turn of the $20^{\text {th }}$ century, the establishment of municipal parks became exceptionally popular. At that time, there were many prominent planners and garden planners called landscape architects. It's especially worth mentioning Walerian Kronenberg, the creator of over 300 parks in the period 1880-1905, Teodor Charzyński, Stanisław Celichowski, Edmund Jankowski, and Franciszek Szanior- among the others the creator of new parks in Warsaw (Sakryszewski Park and Ujazdowski Park) [14]. These newly established parks included a complementary infrastructure, in the form of gazebos and pavilions, sport infrastructure (the influence of game parks of dr. Jordan), and various types of greenhouses and palm houses. Admittedly, these were not as impressive in shape and size as greenhouses of Great Britain or Germany. The latest constructional solutions were also not used. However, an important example of such buildings in Poland are the greenhouses in the Botanical Garden in Wrocław (1861), the hothouse in Kraków (1872) and the palm house in Lubiechów (1911-1914) [16]. One example of the greenhouse - palm house, also known as the "great iron greenhouse" in the Saski Garden in Warsaw were erected in 1854, in its south-western part of the garden, near the square behind the iron gate. A representative parterre preceded the greenhouse. It had a rectangular plan with a design influenced by the humble Anglo-Saxon greenhouses glazed with Polish flat rolled glass, hot water heating systems, and a cast iron structure [17]. The main body of the orangery was accentuated by a centrally placed break, which defined the entrance detailed as a Moorish arch. The single volume interior was rearranged in 1912, when artificial caves and rocks were added to create a backdrop for exotic vegetation stored in the building. The greenhouse was wrecked during the Warsaw Uprising and torn down by the retreating Germans.

In the Lublin region, municipal parks started to be created from the first half of the $19^{\text {th }}$ century. Herein, we will investigate three municipal parks of the Lublin region: the first public gardens in Lublin, Lubartów and Zamość and the function they fulfil presently.

\section{The municipal park in Lubartów}

The palace - park complex in Lubartów is one of the best preserved and reconstructed after the Second World War. The garden exemplifies the baroque composition of the entre cour et jardin ${ }^{l}$. The eight-hectare park, converted to a municipal park in 1935, is one of the most important green areas of this district town of nearly 23 thousand residents. Currently, it functions as a leisure spot for the town residents and accommodates a football field.

Lubartów, originally called Lewartów, was founded by Piotr Firlej from Dąbrowica, who obtained permission for the location its 1543 from the King Sigismund I the Old. The town was founded on the basis of Magdeburg laws "in cruda radice". The centre of the town was the Market Square with a wooden town hall. In the northern part there is a wooden church

\footnotetext{
${ }^{1}$ A garden composition, called "between the courtyard and the garden" (entre cour et jardin), characteristic for the Baroque period, subject to the rigorous rules of the composition.
} 
dedicated to St. Peter, the Apostle. After the fire its name was changed to the church of St. Anne [8]. At that time, a magnate's residence was surrounded by an Italian garden. The Lubartów Palace, along with a park of 18.5 hectares, was called the Lubartów castle.

In the eighteenth-century plan of Hendesfeld, a baroque composition of the entire palace - park complex is visible. It is worth comparing this plan with the description of the garden complex from the 1747 Inventory of Lubartów estates [18]. The main compositional axis of the complex ran through the centre of the palace. It was extended by an alley flanked with lime trees (now road number 20) leading to the palace complex of Kozłówka. In front of the palace there was the main courtyard (cour d'honneur), square in plan, surrounded by annexes built of brick (separating the space from the north and south side) and the main entrance gate at the west. The symmetrical division of the garden by the main avenue, from which the secondary alleys divided, was further emphasized by a circular area with a lawn and two rectangular canals which closed the magnate garden of the east (from the side of the Wieprz river). Interestingly, an empty square is visible on the plan. It has been described in the inventory as follows: "the other half of the garden lanes planted with hornbeams (...) and at the end of the garden, the square where trees froze and died". The water of the "Sadzawka Pańska" pond came from two encased sources located under the bridge near the main courtyard. In the centre there was a round square with a circular lawn. The plan also included buildings accompanying the whole complex, including the hothouse - "orange house of three storeys" (Fig. 1). The park in Lubartów was transformed into an English style gardening 1830, thanks to the new owner, Klementyna Małachowska. This intervention included the demolition of the main entrance gate with the keep and the annexes surrounding the square [7].

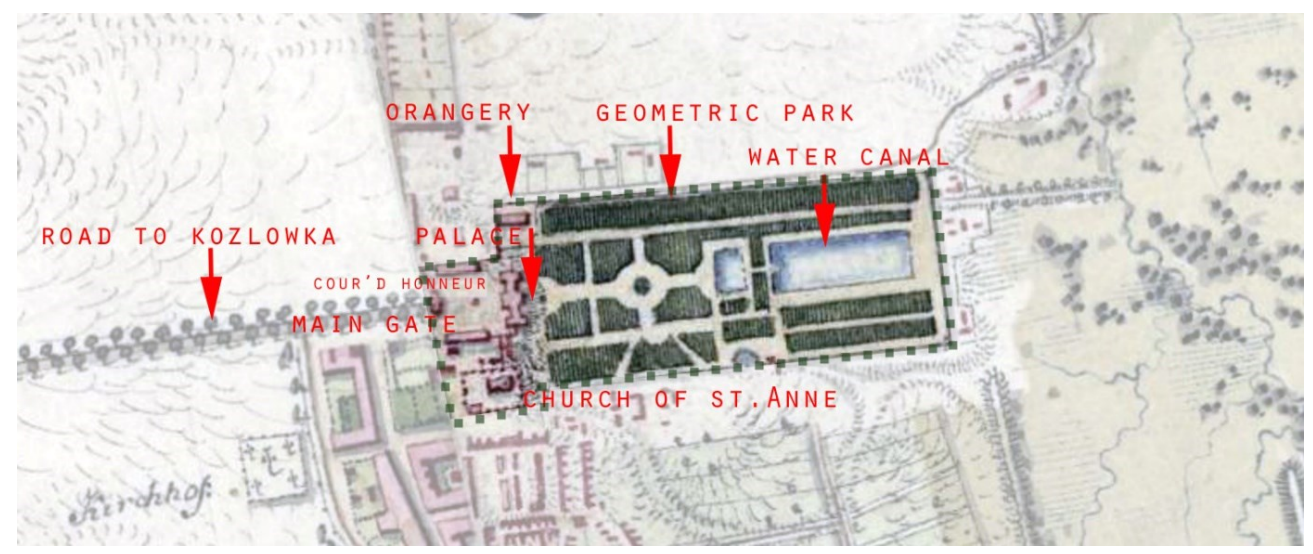

Fig. 1. A part of the plan from the end of the 18th century which shows the most important elements of the complex, author's own elaboration on the basis of fragment Carte von WestGallizien...,1804, Kriegsarchiv, Wien source mapire.eu, access: 08.05.2019

In 1949, thanks to Gerard Ciołek the restoration of the complex according to his designs was partially executed. The baroque park composition layout was reinstated. Until now, there is a historic area covering the space of the first complex. The historical substance of the park in the form of specimen trees dating back to the times of the Firlej and Sanguszko family is represented by individual trees located near the palace and in the northern part of the park by one of the alleys (which in the past was one of the compositional axes). Most of the historic stand of trees is dated to 1840-1934 and is located in the southern part of the park and in the vicinity of the pond. 
The park and its spatial structure in its present state is the result of the restoration carried out in the 1950-1975 according to the plan of Gerard Ciołek and later Anna Obrębska [19]. The project of restoration of the garden complex according to Gerard Ciołek was developed in the 1950s, at a time when various "social functions" were often imposed on historical parks thereby severely damaging then the historical nature and disturbing their historic spatial compositions. This was often of a building - a manor house or a palace and its historical plantings. Gerard Ciołek attempted the reconstruction of the French baroque garden in the immediate vicinity of the palace in order to recreate a kind of garden salon.

The nineteenth-century part in the English style remained largely unchanged, apart from small interventions - like the creation of island in the pond. The northern part of the establishment was to be a garden theatre in the form of cabinets stretching along the baroque water channel (Fig. 2). It was complemented with a complex of sport fields and a representative garden emphasizing the building of the Baroque-Classicist hothouse. These plans were only partially implemented - the garden salon was reconstructed next to the palace, while in the northern part, a sports stadium was built together with back-office buildings and an amphitheatre in the place of the planned complex of sports fields [7]. We can say that the historical park in Lubartów shared the fate of many other garden complexes transformed into municipal parks. It lacks the proper maintenance and care for the historical stands resulted in the blurring of the perspective axes that were landscape connections with the Wieprz River and riverside meadows.

Currently, the city of Lubartow is one of the five municipalities involved in the partnership project called "Zielony LOF" (the Green Lublin Functional Area). This project is co-financed by the European Regional Development Fund as a part of the Regional Operational Program of the Lublin Voivodeship for the period of 2014-2020. The project is focused on increasing the biodiversity of the covered areas by improving the quality of green areas along with their management and limiting the impact on the areas. One of the tasks of the project is "modernization of the municipal park and supplementing the infrastructure to enhance tourist attractiveness of Lubartów". Within the framework of this mission, the arrangement of the entire park, included the introduction of new functions (areas of activity for children and adults) together with the necessary infrastructure, pond cleaning and adaptations [20].

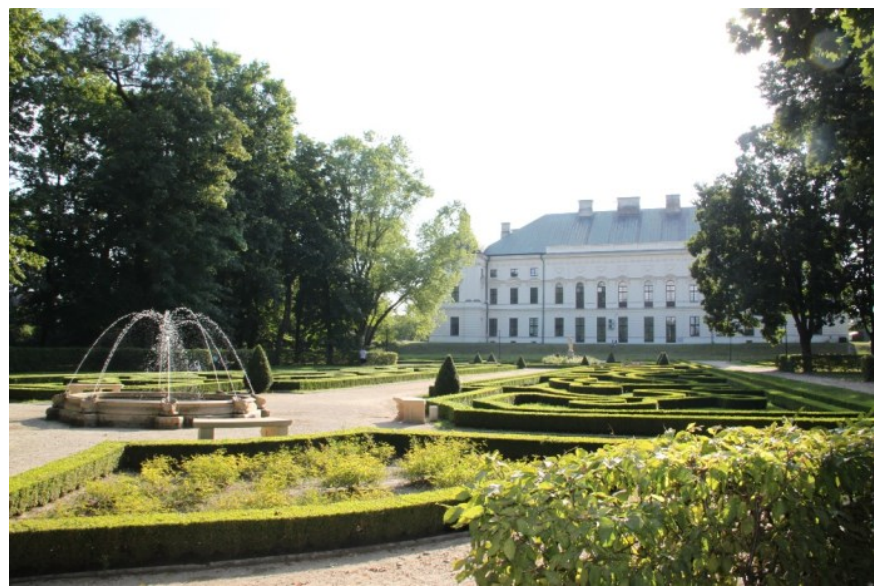

Fig. 2. Park in Lubartów, current state, photo by author 


\section{The hothouse as a node element of the park in Lubartów.}

One of the most important facilities complementing the infrastructure of the park was the greenhouse building located in the north-west part of the complex. It is one of the largest hothouses accompanying a mansion complex in the Lublin Voivodeship. The building was built in the Classicial style and is first mentioned in 1703. The hothouse is a one-storey block with a two-storey part at the east, made in the shape of L. Orangery had a 23-bays on the south façade. It is a brick building covered with a hipped roof covered in ceramic roof tiles (Fig. 3). This building was originally used to keep orange trees during the winter season. Later, during the interwar period, it was adapted to residential function. It was used for this purpose until the 1960s. In 2000, its structural condition was catastrophic. In 2005, the building was sold, and in 2010 , only the southern wall and a fragment of the eastern wall remained from the building of the former greenhouse [10]. If we analyse the history of the similar buildings, one might have expected that the Lubartów hothouse would disappear from neglect. However, the building was purchased by a private investor who has been rebuilding it over numerous years. The architectural detail of the building and the divisions of window joinery have been respected and reproduced with a great accuracy. This object is to be used for hotel and restaurant function [21] (Fig. 4).

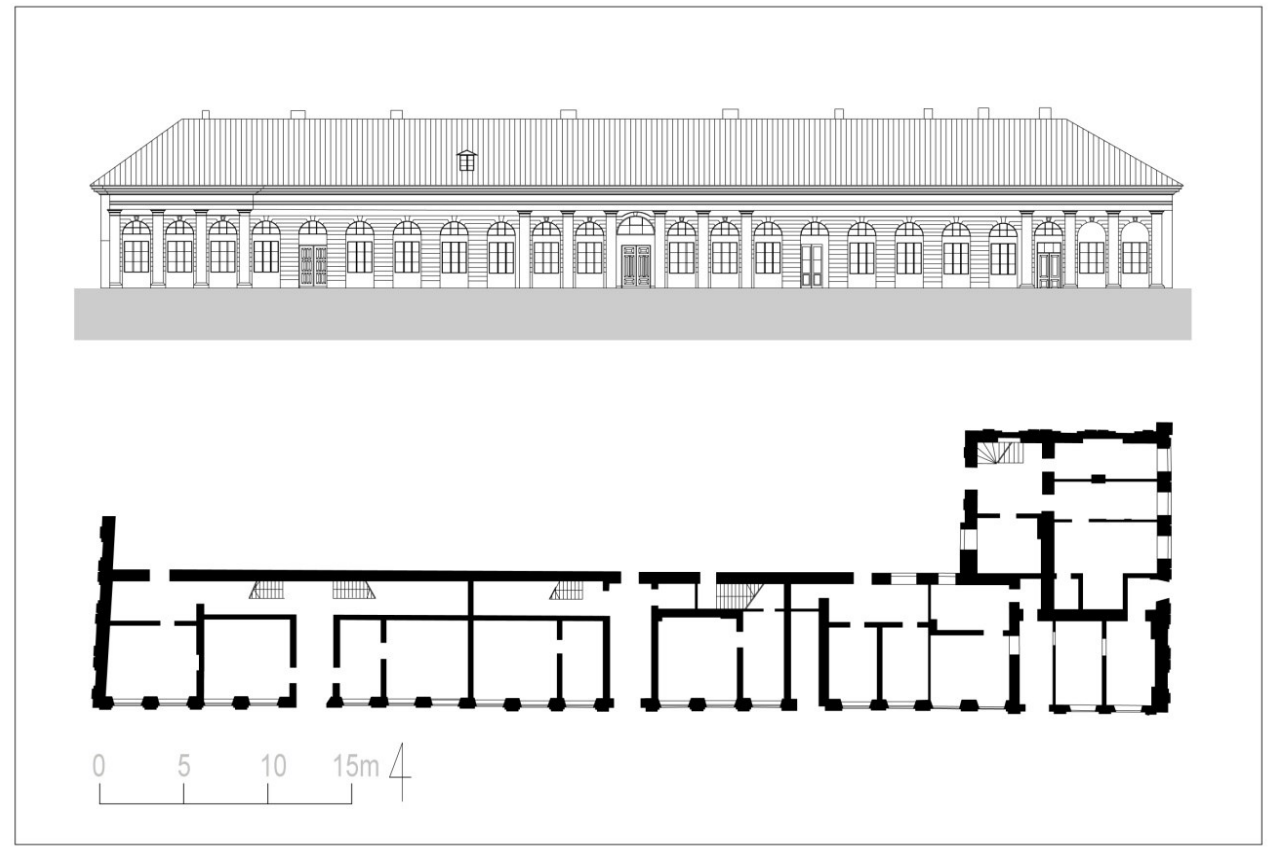

Fig. 3. The schematic plan and façade of the hothouse in Lubartów, author's own elaboration 

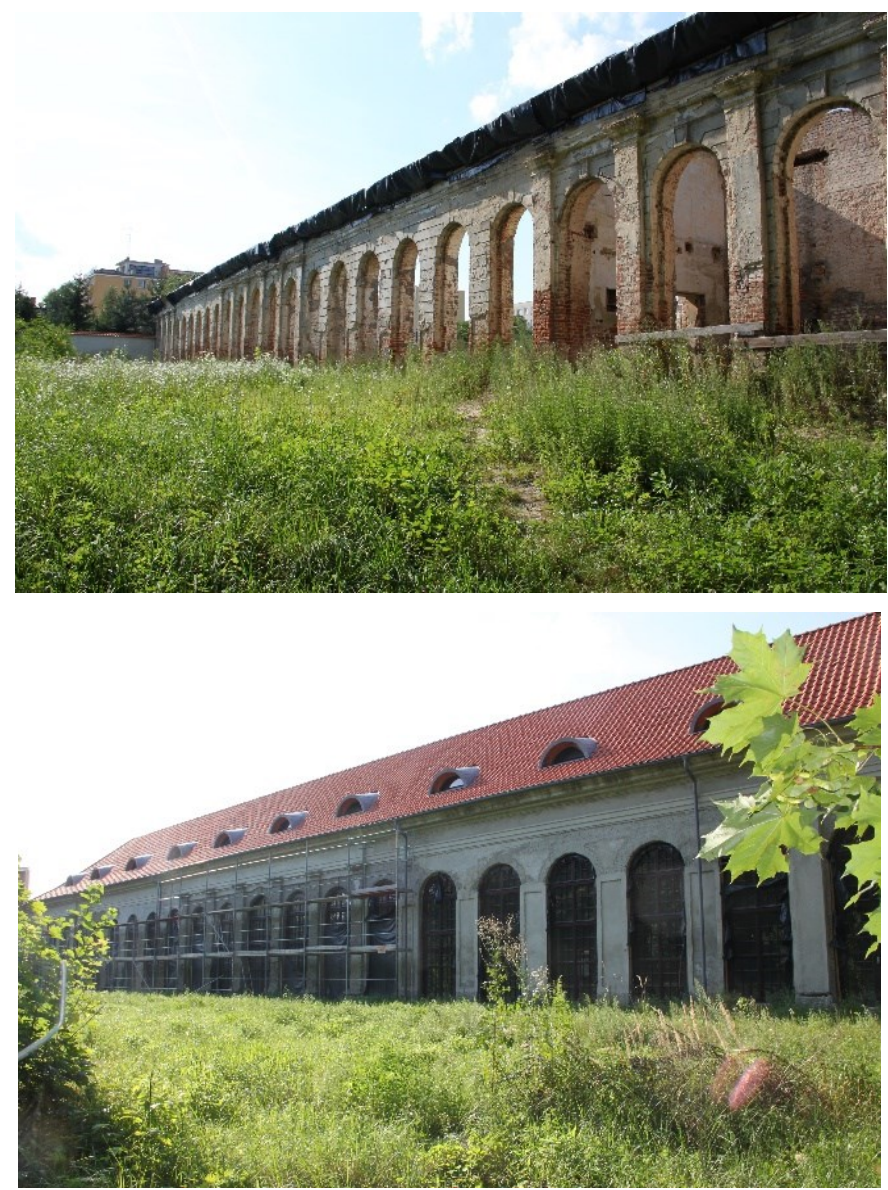

Fig. 4. The hothouse in Lubartów in 2005 and 2018, photo: author

\section{The Saski Garden (Ogród Saski) in Lublin}

The establishment of the Saski Garden (1837) in Lublin is connected with the work of the gubernatorial engineer Feliks Bieczyński, originator and planner of the nineteenthcentury municipal parks of Lublin: a park in the area of the Jewish city, Bronowice park (1869) "located in the area of the city between the Czerniejówka river and the suburbs of Piaski" or unrealized concept of a housing estate and park from 1860.

The Saski Garden was located "by the paved road to Warsaw" on the former Dominican properties [22]. The choice of the plot for the future municipal park was made due to the advantageous ownership and economic situation of the plot, the improvement of the quality of the "wretched city of Wieniawa" adjacent to the future investment, varied topography and relief, "vast views" and "proximity of the city" [23]. The park was made in a landscape style; the organic layout of communication routes has been composed as an element that was binding individual landscape interiors. The elements of landscape architecture were complementing the layout of the park. Bieczyński designed among the others a well, an entrance gates to the park, a guardhouse, or an unaccomplished adaptation of the building of the old powder-magazine for the function of gardener's house (Fig. 5). 


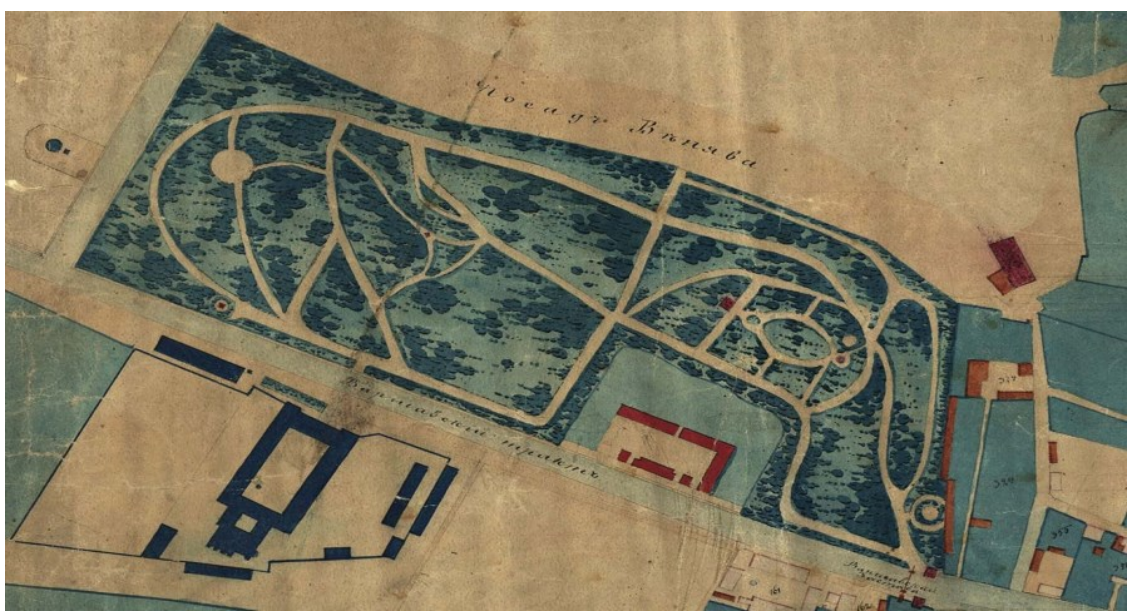

Fig. 5. Archival plans of the Saski Garden in Lublin, fragment План города Люблина 1870, source: State Archives, s. 5, План города Люблина, 1870, Piotr Cegliński, Lubelskie Archiwum Cyfrowe

\section{An unexecuted plan for the Hothouse Pavilion}

At the end of the 1950s, there were plans to locate the palm house in the Saski Garden. The opinion of an expert was commissioned for the needs of the local plan "in which basic requirements were defined and the significance of this type of garden architecture was characterized as: educational, didactic and tourist". Therefore, the study underlines that this type of facility should be located in municipal parks, and the most representative and well located in terms of communication was the oldest municipal park of Lublin called the Saski Garden (Ogród Saski). The area devoted for the construction of a new building was a rectangular, flat square created after repurposing of an agricultural farm. It bordered on two sides with the old-growth trees of the municipal garden, and on the other side with the building formerly called the House of Party, currently housing the Rector's Office of the Medical University. Placing of such an important architectural building necessitated the plans to change the main entrance to the park, whereas the palm house was to "stand on the background of the old-growth trees of the park as far as possible from Racławicka street, and the entire flat area was to be transformed into a representative flower garden, separated from the street with a belt of trees and bushes" (Fig. 6) [24].

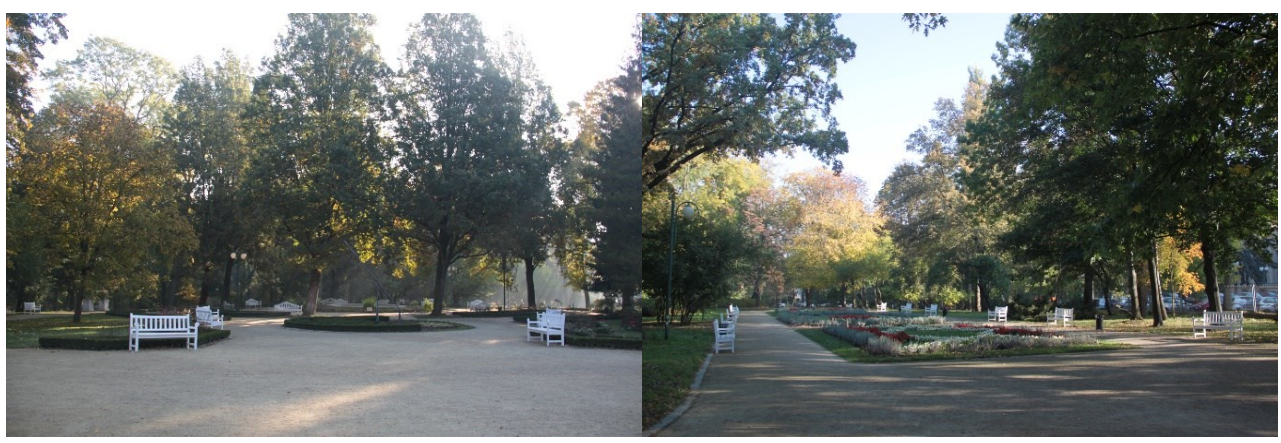

Fig. 6. The Saski Garden in Lublin, current state, photo by Wojciech Pawlak 


\section{The municipal park in Zamość}

In 1924, an exhibition of plans of parks and gardens was organized in Warsaw by the Planners' Club of the Warsaw Horticultural Society. Its main goal was to popularize the art of landscape planning. Twenty planners associated in the Planners' Club together with the different institutions took part in the event lasting nearly a week. About 100 plans were presented at the exhibition. One of them was sent by the city of Zamość and "presented the plan of the park on the fortress ramparts, developed and perfectly adapted to the conditions by Mr. Walerjan Kronenberg, a well-known planner" [25].

The residents of Zamość made efforts to create a municipal park date back to 1903 when the first steps were taken in this direction. However, only after World War I, in 1917, after the consultations with the Warsaw Horticultural Society, the city of Zamość announced a two-stage architectural competition for the concept of municipal park development. The work of Walerian Kronenberg, a renowned garden planner specializing in establishing garden complexes at parks and manors, the author of city parks in Warsaw (1903-1904) - (Agrykola), Łódź (1904-1910), was selected for this task. The planner's works also include projects of spa parks in Nałęczów (recomposition and enlargement of the park), Konstancin Jeziorna or municipal parks in Białystok and Spała. The works on the park lasted for 8 years and were supervised by the designer himself.

The municipal park in Zamość represents the early modernism. It was made in the form of landscape and geometric park (Fig. 7). The complex designed by Walerian Kronenberg differed significantly in terms of the composition and style from the calligraphic parks designed before by the planner. It is an example of an innovative approach to the "devastated fortress landscape", which determined the ultimate character of the complex through its topography, thus showing the identity of this place. The functional - spatial composition of the park was closely related to the remains of the seventeenth-century bastion fortification left after demolition. The park was founded in the area of three fortresses: Bastion $I V$, the counterguard of the same bastion and ravelin in front of the curtain between Bastion IV and $V[26]$.

The way of shaping the communication routes and the water system (the pond and the island highlighting the former counterguard of the bastion) emphasized the historical outline of the fortifications and made them legible in the composition of the whole complex ${ }^{2}$. Bastion IV is currently not an "orderly relic" but an example of the original architectural creation of the old fortress. As a result of the program "Zamośc, a city of UNESCO, the Monument of the History of the Republic of Poland, as a tourist product of the Polish economy", the bastion was opened to the public and is a great view point for the modernist garden complex, just like the over-bulwark, from which the panorama of the city of Zamość can be admired [26]. The other part of the park (on its eastern side) is a highly geometricized, representative part consisting of two garden interiors intersecting at a right angle with a centrally placed fountain [3] - the whole is inscribed in the former ravelin in front of the main gate and the bridge stretched over the system of fortifications. Currently, this space is used by go-carts that are a tourist attraction of the park (Fig. 8).

2 ,The introduced new elements serve to visually link the bastion with the circumference of the fortifications. The readability (integration) of earth elements and the correction of greenery on Bastion IV with plantings in the background of the bastion (outfield), the use of defence devices around the pen, and the appointment of the area (information boards) were made. Casemates of Bastion IV were intended for tourist functions ". http://twierdza.zamosc.pl/pl/places/222/parkmiejski-bastion-iv-sloniczolo-przed-bastionem.html, access: 19.12.2018 


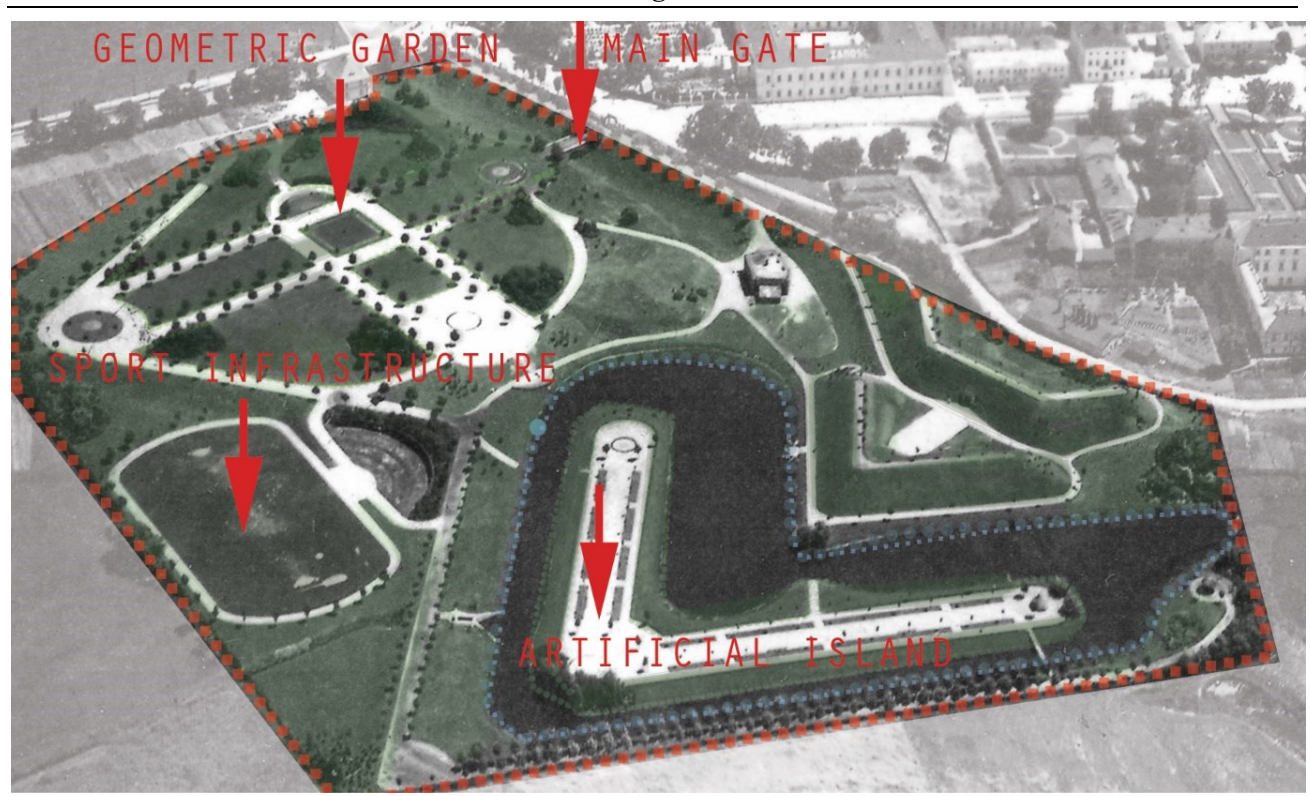

Fig. 7. Schematic plan of park in Zamość, author's own elaboration on the basis of the photo in archive of Instytut Sztuki PAN in Warsaw, nr 18373 (1927)
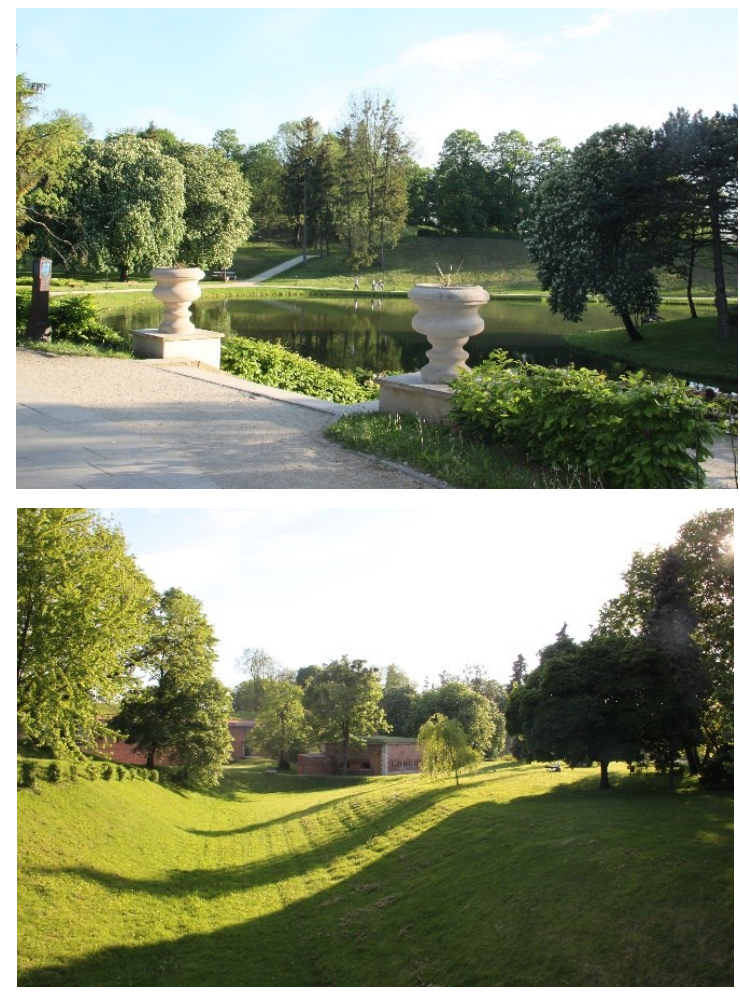

Fig. 8. The municipal park in Zamość, current state, photo by author 
In terms of functionality, the municipal park in Zamość is analogic to the functional program of the Palmgarten park in Frankfurt designed by F. H. Siesmayer in 1868-1887, when Valerian Kronenberg had his apprenticeship there (in the 1870s). Just like in the German public garden, the "Great Garden Salon" decorated with floral patterns ("Wielki Staw" - the Big Pond) was designed in Zamość. There was also garden architecture in the form of cafés, gazebos, three bridges leading to the island and other decorative elements like compositions of flower parterres or lapidarium in the form of the boulders near the pond.

A very important element of the public gardens of the early $20^{\text {th }}$ century was the sport infrastructure represented in the garden in Zamość by a square of 4.5 thousand $\mathrm{m}^{2}$ with an audience and running track, a tennis court and a playground for children. The trend of designing new forms of recreation in the open space has been gaining more and more popularity since the end of the $19^{\text {th }}$ century due to the game parks of dr. Jordan [3].

\section{The greenhouse}

The building of the former greenhouse is currently used for a florist's shop. It was built in the 1930s and was based on the modest greenhouses accompanying manor gardens. The building built on the circular plan is in the form of a rotunda with the vestibule in front of the entrance. The building had a surface of $290 \mathrm{~m}^{2}$ and its height was four meters. The building material and cast iron windows arranged symmetrically in the facade were obtained from the demolition of the "Unia" factory located at Lwowska street. There was a chimney in the central part of the greenhouse. Smoke channel in the external walls was used to heat the greenhouse [5] (Fig. 9).

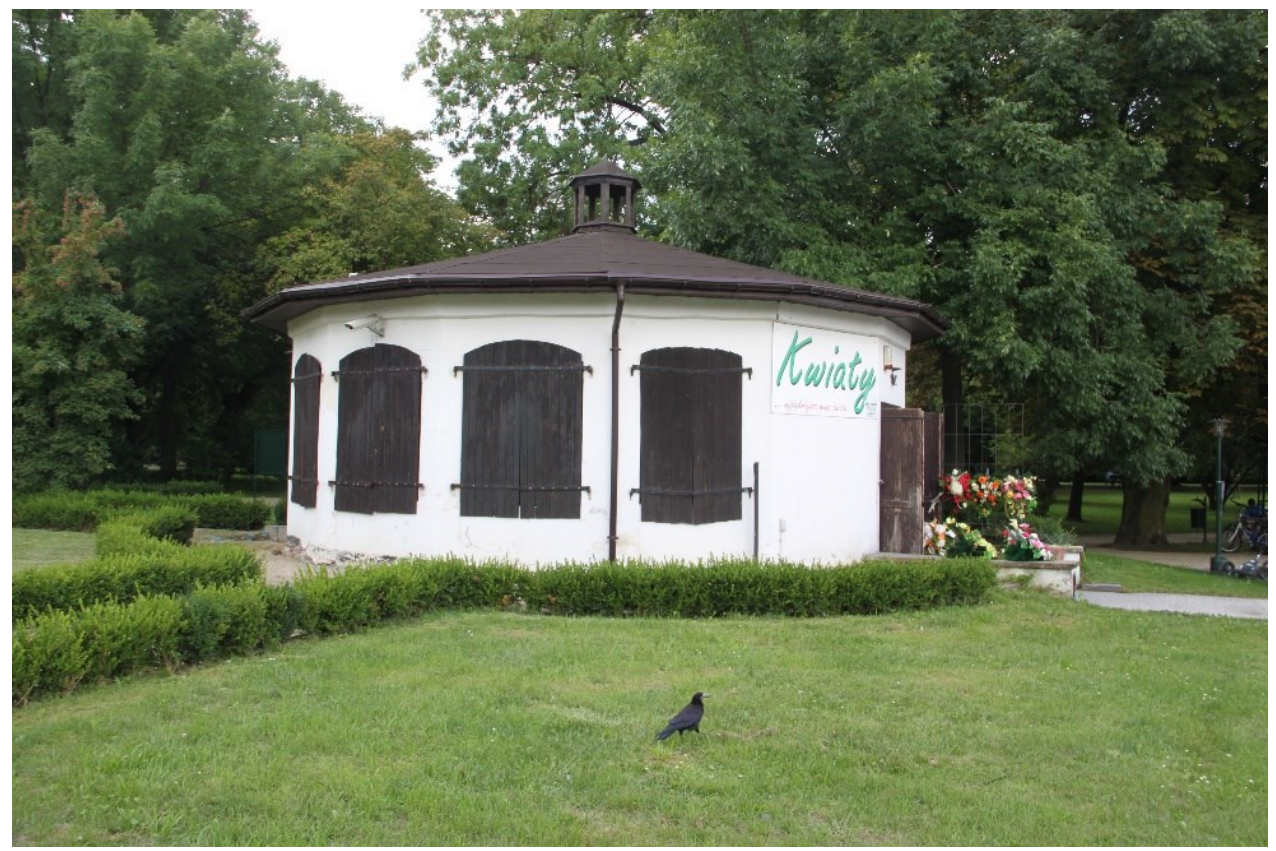

Fig. 9. The building of the former greenhouse and now the florist's shop, current state, photo. author 


\section{Summary}

The gardens listed in the table below (Tab. 1) are undeniably among of the most important green areas of the above-mentioned cities. They are the tourist gem and the place for leisure of their residents. The area of these urban gardens is quite significant - they range from 8 to 11 hectares (Tab. 1). Nowadays, they are an important element of the city centre (Lublin, Lubartów) or they border directly with the Old Town (Zamość). They were created at very different periods of time (Tab. 1) and in a different way, starting from the magnate foundation (Lubartów), through the planned action of greening of the city (Lublin), to an architectural competition project (Zamość). However, they have one thing in common - the areas for their location were interesting in terms of landscape and located outside of then borders of the city centre. An exception here is the park in Zamość, which was designed to respect the existing fortifications system adapting it to new functions. Only this park has still documentation of the plan by Walerian Kronenberg. For the other sites in Lublin and Lubartów, we know the landscape plans of the parks only from later city development plans.

Noteworthy is the fact that the parks in Lublin and Zamość had a very rich functional program as opposed to the park in Lubartów, which originally was supposed to be a garden accompanying the palace. Especially the garden in Zamość, which based its plan on German models and was created almost the same time as the game parks of dr. Jordan of the early twentieth century, was characterized by a large sport area in the form of: a sports square of 4.5 thousand $\mathrm{m}^{2}$ with a running track, a tennis court, kayaks and an ice rink in the winter at the pond (Tab.1).

In observing the degree of preservation of these historical compositions - currently two parks have been restored (Lublin, Zamość) and their spatial composition has been preserved in nearly unchanged. The garden in Lubartów is currently classified as one of the better reconstructed (1950s and 1960s) Baroque complexes Entre Cour et Jardin in the Lublin region, although the later character of landscape park from the nineteenth century is mostly visible from the eastern part by the pond. This park, however, did not escape the devastation, influenced on manor complexes in the aftermath of "pro-social" decisions of the 1950s (a sport stadium was located within the borders of the park).

Currently, there are a few significant changes in the area of the parks. They are more accessible due to better space organization and they give more sense of security thanks to the implementation of monitoring (Lublin, Zamość). The historical functions of the park are currently being recreated. For instance in Zamość, by the end of 2019 the construction of a park cafe will be completed (such building once existed in the area of the park). Whereas in Lubartów, the hothouse was rebuilt.

Table 1. The transformations in the functional and spatial use of the analysed parks, author's elaboration based on literature, archives and internet sources

\begin{tabular}{|c|c|c|c|}
\hline $\begin{array}{l}\text { The name of the } \\
\text { complex }\end{array}$ & $\begin{array}{l}\text { Palace - park } \\
\text { complex in } \\
\text { Lubartów }\end{array}$ & $\begin{array}{l}\text { The municipal park } \\
\text { in Lublin , Ogród } \\
\text { Saski” - Saski } \\
\text { Garden }\end{array}$ & $\begin{array}{l}\text { The municipal garden in } \\
\text { Zamość }\end{array}$ \\
\hline $\begin{array}{l}\text { The current style } \\
\text { of the garden, } \\
\text { the form } \\
\text { transformation } \\
\text { and function, the } \\
\text { time of } \\
\text { establishment }\end{array}$ & $\begin{array}{l}\text { The first half of } 18 \text { th } \\
\text { century. } \\
\text { Baroque palace park / } \\
\text { later landscape park, } \\
\text { in the } 50 \text { 's and } 60 \text { 's } \\
\text { restored by G. Ciołek }\end{array}$ & $\begin{array}{l}1837, \\
\text { landscape public park, } \\
\text { (municipal) }\end{array}$ & $\begin{array}{l}\text { 1919-1926, Modernist, } \\
\text { public garden taking into } \\
\text { account and exhibiting in } \\
\text { its topography and } \\
\text { architectural forms } \\
\text { elements of the former } \\
\text { fortifications of the city of } \\
\text { Zamośc }\end{array}$ \\
\hline
\end{tabular}


Municipal gardens as the synergic element of the structure...

\begin{tabular}{|c|c|c|c|}
\hline $\begin{array}{l}\text { Planner / } \\
\text { founder }\end{array}$ & $\begin{array}{l}\text { Sanguszko family } \\
\text { Palace - park } \\
\text { complex transformed } \\
\text { into municipal park in } \\
1935 \\
\end{array}$ & $\begin{array}{l}\text { Eng. } \\
\text { Feliks Bieczyński } \\
\text { Lublin city }\end{array}$ & $\begin{array}{l}\text { Walerian Kronenberg/ } \\
\text { Zamość city, park } \\
\text { developed as a result of } \\
\text { an architectural } \\
\text { competition }\end{array}$ \\
\hline $\begin{array}{l}\text { Surface } \\
\text { The time of } \\
\text { restoration }\end{array}$ & $\begin{array}{l}8 \text { hectares, pond: } 3,54 \\
\text { hectares, } 2017 \text { - end } \\
\text { of } 2018\end{array}$ & $\begin{array}{l}12 \text { hectares, } 2009 \text { - } \\
2013\end{array}$ & 11 hectares \\
\hline $\begin{array}{l}\text { Original } \\
\text { functional } \\
\text { program of the } \\
\text { park }\end{array}$ & $\begin{array}{l}\text { Baroque residential } \\
\text { garden - the kind of } \\
\text { entre cour et jardin. } \\
\text { The main courtyard, a } \\
\text { palace with brick } \\
\text { annexes, a baroque } \\
\text { garden salon, a } \\
\text { hothouse, and a water } \\
\text { channel. }\end{array}$ & $\begin{array}{l}\text { Fenced landscape } \\
\text { municipal park with a } \\
\text { pond and a cascade, a } \\
\text { neo-gothic } \\
\text { guardhouse, pavilions } \\
\text { - a gazebo - a } \\
\text { patisserie, a circular } \\
\text { gazebo, two fountains } \\
\text { (19th- and 20th- } \\
\text { century), a sundial, a } \\
\text { baroque sculpture } \\
\text { erected on a mound } \\
\text { during the war by the } \\
\text { Germans, Tyrolean } \\
\text { tavern }\end{array}$ & $\begin{array}{l}\text { Garden salon consisting } \\
\text { of two garden parterres } \\
\text { with fountains, a } \\
\text { representative main gate } \\
\text { Café, Big pond available } \\
\text { to residents (in summer, } \\
\text { there is a boat, in winter - } \\
\text { an ice rink). } \\
\text { Three garden bridges } \\
\text { leading to the island. } \\
\text { A lock in the shape of a } \\
\text { mushroom, lapidarium at } \\
\text { the pond. A sports square } \\
\text { of } 4.5 \text { thousand m2 with a } \\
\text { running track. Auxiliary } \\
\text { garden with greenhouses } \\
\text { and a nursery. Children's } \\
\text { Playground, Building and } \\
\text { pavilion for the orchestra, } \\
\text { tennis court }\end{array}$ \\
\hline $\begin{array}{l}\text { Current } \\
\text { functional } \\
\text { program of the } \\
\text { municipal park }\end{array}$ & $\begin{array}{l}\text { A walking park, in the } \\
\text { palace there is } \\
\text { currently the } \\
\text { Lubartów Town } \\
\text { Office, the pond is } \\
\text { unused (fishing with a } \\
\text { permission), a } \\
\text { baroque salon next to } \\
\text { the palace, the } \\
\text { hothouse in the } \\
\text { private hands in the } \\
\text { middle of a major } \\
\text { overhaul to adapt the } \\
\text { building for restaurant } \\
\text { and hotel function, the } \\
\text { restoration project of } \\
\text { the complex is ready. }\end{array}$ & $\begin{array}{l}\text { Fenced park, surface } \\
\text { was replaced, } \\
\text { renovated water } \\
\text { system, (construction } \\
\text { of a new pond), an } \\
\text { aviary, an } \\
\text { amphitheatre, } \\
\text { renovation of a neo- } \\
\text { gothic guardhouse }\end{array}$ & $\begin{array}{l}\text { Walking park, garden } \\
\text { salon (go-cards, bicycles), } \\
\text { sport area, a pond } \\
\text { accessible for the } \\
\text { residents (kayaks), the } \\
\text { plans to build a cafe, a } \\
\text { bastion open for tourists, } \\
\text { a former hothouse } \\
\text { functioning as a florist. }\end{array}$ \\
\hline $\begin{array}{l}\text { The cost of } \\
\text { restoration plan }\end{array}$ & $\begin{array}{l}\text { PLN } 10 \text { million as } \\
\text { part of the Zielona } \\
\text { LOF partnership } \\
\text { project planned for } \\
2016-2020\end{array}$ & $\begin{array}{l}\text { PLN } 12.7 \text { million, co- } \\
\text { financing in the } \\
\text { amount of PLN } 7.3 \\
\text { million from the } \\
\text { European Regional } \\
\text { Development Fund }\end{array}$ & PLN 11 million project \\
\hline
\end{tabular}




\section{References}

[1] Majdecki L., „Historia Ogrodów od XVIII wieku do współczesności”, Wydawnictwo Naukowe PWN, Warszawa 2008, p. 359

[2] Przesmycka N., Boguszewska K., „Kształtowanie terenów zieleni w układzie urbanistycznym śródmieścia Lublina”, 2018, typescript

[3] Kulus V., Kronenberg W., „Materiały do słownika twórców architektury krajobrazu w Polsce, T1", Wydawnictwo SGGW, 1990, pp. 36, 61-62

[4] Baster P. „Polskie parki kaligraficzne”, Wydawnictwo AGH, Kraków 2011

[5] Sawa B., „Dzieje zamojskiego parku”, Zamojski Kwartalnik Kulturalny, no. 1-2 (78-79) 2004, Zamość, Zamojski Dom Kultury, 2004, pp.96-97

[6] Pudelska K., Rojek K., „Zmiany w strukturze drzewostanu w XIX wiecznym parku w Czesławicach", Teka Komisji Architektury, Urbanistyki i Studiów Krajobrazowych, OL PAN 2013, IX/3, pp. 56-63

[7] Kseniak M., „Parki i ogrody dworskie w województwie Lubelskim”, 1983, Lublin, pp. 34, 3638

[8] Przesmycka E., „Przeobrażenia zabudowy i krajobrazu miasteczek Lubelszczyzny”, Wydawnictwo Politechnika Lubelska, 2001, p. 168

[9] Grytczuk R., Kuźmicz M., „Projekt rewaloryzacji zespołu pałacowo-parkowego w Lubartowie z adaptacją oranżerii na cele współczesne”, praca magisterska, Politechnika Lubelska, Lublin 2001, pp.85, 110,

[10] Przesmycka E., Boguszewska K., „Losy Oranżerii w Lubartowie”, Teka Komisji Architektury, Urbanistyki i Studiów Krajobrazowych, OL PAN 2011, pp. 126-131

[11] Boguszewska K., „Oranżerie województwa lubelskiego w świetle polskich wzorników sztuki ogrodowej z XIX i XX wieku", Annales Universitatis Mariae Curie-Skłodowska. Sectio L, Artes, vol. 11, 1 (2013), pp. 9-25. https://doi.org/10.2478/umcsart-2013-0007

[12] Niedźwiedź J., „Ogrody Lublina w planistycznej twórczości Feliksa Bieczyńskiego”, Czasopismo Techniczne. Architektura, R. 104, z. 5-A, 2007

[13] Przesmycka N., „Przeobrażenia historycznych terenów zielonych Lublina do 1939 roku”, Teka Komisji Architektury, Urbanistyki i Studiów Krajobrazowych, OL PAN, 2005, pp. 157-167

[14] Ciołek G., „Ogrody polskie”, Wydawnictwo Arkady, Warszawa 1978, p. 180

[15] Jankowski E., „Ogrody publiczne w miastach prowincjonalnych”, Warszawa 1892, pp. 554, 555

[16] Gronostajska B., „Historia powstania oranżerii”, Architectus, vol. 1(11) 2002, pp.112-113

[17] Kraushar A., „1727-1927 w dwuchsetną rocznicę oddania Ogrodu Saskiego do użytku publicznego", Warszawa "WUZET", 1927, p.15

[18] „Inwentarz dóbr lubartowskich jaśnie oświeconych na Białym Kowalu, Smolanach i Rakowie, Zasławiu i Ostrogu książąt ichmościów Sanguszków, na Wiśniczu, Jarosławiu i Tarnowie Hrabiów, marszałków wielkich Wielkiego Księstwa Litewskiego, krzemienieckich i czerkaskich starostów, spisany na gruncie z pomiarem in anno 1747", Archiwum Narodowe w Krakowie, Archiwum Sanguszków, sign. 581, 5-327, za: Za: M. Kseniak Parki i ogrody dworskie w województwie Lubelskim, 1983, Lublin, p. 36

[19] Cebula A., Kunkel A., Projekt koncepcyjny przebudowy parku miejskiego w Lubartowie działki nr ewidencyjny 218/2 i 223 obręb Lubartów, Warszawa 2017

[20] http://lubartow.pl/projekty_unijne/102709/zielony_lof/, [Access: 15 Dec 2018].

[21] http://przegladlubartowski.pl/informacje/17773/ruszyl-remont-lubartowskiej-oranzerii, [Access: 15 Dec 2018].

[22] Żywicki J., „Urzędnicy: Architekci, Budowniczowie, inżynierowie cywilni..., Ludzie architektury i budownictwa w województwie lubelskim oraz guberni lubelskiej w Królestwie Polskim a latach 1815 - 1915”, Wydawnictwo UMCS, Lublin 2010, p.147 
[23] Targońska E., „Najstarszy ogród w mieście”, Apla Biuletyn. Pamiętajcie o ogrodach, APL, No.2, 2011, p. 2.

[24] Lisiak B., „Ekspertyza techniczna planu zieleni miasta Lublina na etap 1955 - 1965”, Poznań, 1957, Archiwum UM w Lublinie.

[25] Szanior F., „Wystawa planów parków i ogrodów”, Ogrodnik, R. 14, no. 13-14, 1-15.07.1924, p.172-173.

[26] http://twierdza.zamosc.pl/pl/places/222/park-miejski-bastion-iv-sloniczolo-przedbastionem.html, [Access: 19 Dec 2018] 